\title{
An Analysis on Scrum Methodology in Global Software Development - GSD
}

\author{
AREEBA AHMAD, JOAN LU, STEVE WADE, RICHARD HILL, LEE MCCLUSKEY
}

U2051024@unimail.hud.ac.uk; j.lu@hud.ac.uk;s.j.wade@hud.ac.uk;r.hill@hud.ac.uk;t.l.mccluskey@hud.ac.uk

\begin{abstract}
The development of applications in collaborative production environments poses problems relating to teamwork, control and communication. Global software development (GSD) has increasingly identified agile techniques that require regular contact and selforganization between remote sites to mitigate challenges. The main aim of this paper is to present an analysis of the challenges in GSD using Scrum practices. This study discusses the Scrum practices in GSD from existing database libraries from 2009 to 2020 . It is found that there is relatively quite wide activity in the area of GSD and it may be difficult to apply Scrum in GSD but it provides solutions to the issues people face in this area.
\end{abstract}

Keywords-Agile approaches, Global Software Development, Scrum, Scrum practices.

\section{INTRODUCTION}

$\mathrm{G}$ lobal Software Development (GSD) offers cost savings, and reduced market time (Vallon, et al, 2018, Shameem et al, 2020).

It is a new trend in which IT service providers use global resources and continue their practice to achieve higher efficiency levels (Sriram \& Mathew, 2012). This research seeks to understand the fit between agile methodologies and the development of global applications, and thus contribute to the increasing knowledge in GSD (Mathew \& Sriram, 2012). We chose "Scrum" because it focuses on daily project management and commonly used agile method. A rising number of GSD project managers are taking serious account for the use of Scrum practices in their development (Hossain, et al, 2009). The next section gives an overview of the Scrum method and discusses the research background for this research. Section III explains the methods used in review. Section IV describes the results. Section V addresses the findings to draw conclusions. Section VII addresses the limitations of review.

\section{RESEARCH BACKGROUND}

This section includes a brief overview of the GSD Challenges and Scrum practices to clarify the essence of the proposed research structure. In this section, Scrum practices, role of Scrum in GSD and the need for this analysis is shown.

\section{A. Scrum}

Scrum is an iterative and systematic approach to project management. In Scrum, software is distributed in increments called "Sprints". Sprints start with planning and finishes with analysis and review (Hossain et al., 2009). Every sprint allows opportunities for improvements for the succeeding sprint. This is the reason scrum is very flexible through sprint cycles. It allows the developers to share their ideas in the manner of suggestions. They examine and discuss all the barriers requiring contribution from other team members. In this way, they overcome their impediments they have had or will have (Bhavsar, et al, 2020).

\section{B. Scrum in GSD}

With several collocated development teams, Scrum has already found a successful and effective method for managing projects (Hossain et al., 2009).

All old methodologies became unsuccessful because Scrum proved to be very flexible in making changes in development of software at any phase. Now, people can develop software in very less time than past.

\section{Review's Objectives}

Scrum teams are encouraged by regular contact. Thus, the implementation of Scrum practices in GSD projects is evidently difficult because team members are physically separated (Hossain et al., 2009).

Study suggests that project management practices, i.e. Scrum practices are most common among other agile practices. Therefore, Scrum is becoming increasingly popular as an agile tool and can be used for globally dispersed teams. Due to global projects, it was decided to find and explain different challenges and techniques to deal with them to support Scrum (Hossain et al., 2009). 
A large amount of related literature was presented over the years. In 2009 Hossain et al. studied and identified different challenges about scrum in GSD and gave suggestions to overcome these challenges. Similarly, Ansari and Doda (2010) described the use of scrum in GSD with very effective way. This literature review is written using these researches.

\section{RESEARCH METHODS}

There are following three primary stages, used to provide necessary steps, shown below in Figure. 1.
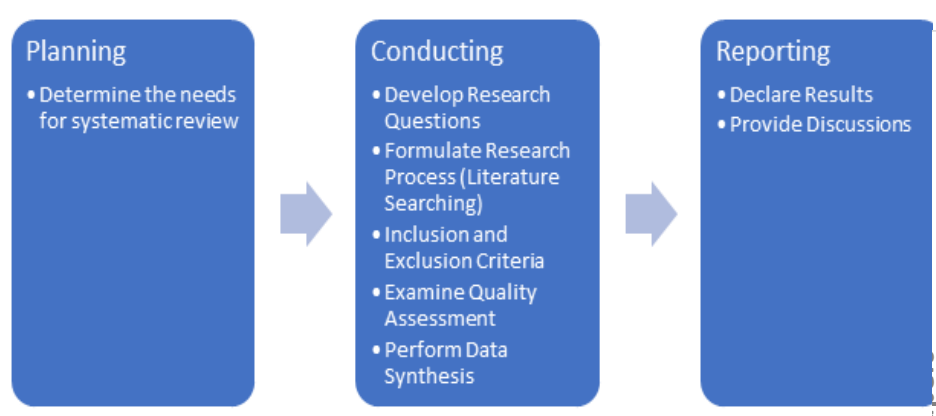

Figure. 1 STAGES OF RESEARCH

These are following research methods used to conduct review.

A. Research Questions (RQs)

The main aim of this review is to address the followin questions in research listed in table 1.

TABLE 1

RESEARCH QUESTIONS ALONG WITH MOTIVATION

\begin{tabular}{|c|c|c|}
\hline ID & RQs & $\begin{array}{l}\text { Motivati } \\
\text { on }\end{array}$ \\
\hline $\begin{array}{l}\text { RQ } \\
1\end{array}$ & What is the role of scrum in GSD? & $\begin{array}{l}\text { Identify } \\
\text { role of } \\
\text { scrum in } \\
\text { GSD. }\end{array}$ \\
\hline $\begin{array}{l}\text { RQ } \\
2\end{array}$ & $\begin{array}{l}\text { What factors cause restrictions in } \\
\text { use of scrum for GSD? }\end{array}$ & $\begin{array}{l}\text { Identify } \\
\text { challengi } \\
\text { ng factors } \\
\text { cause } \\
\text { restriction } \\
\text { s for } \\
\text { scrum in } \\
\text { GSD. }\end{array}$ \\
\hline $\begin{array}{l}\mathrm{RQ} \\
3\end{array}$ & $\begin{array}{l}\text { What techniques and methods are } \\
\text { widely used to tackle these issues } \\
\text { in GSD? }\end{array}$ & $\begin{array}{l}\text { Determin } \\
\text { e the } \\
\text { technique } \\
\mathrm{s} \text { used to } \\
\text { deal with } \\
\text { challenge } \\
\mathrm{s} \text { in use }\end{array}$ \\
\hline
\end{tabular}

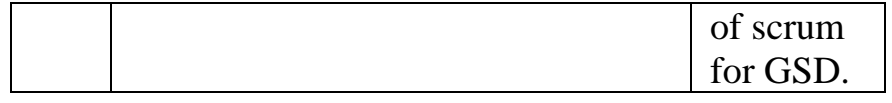

B. Databases for Literature Researching

This study was applied on following libraries:

- IEEE Xplore (ieeexplore.ieee.org)

- Diva Portal (diva-portal.org)

- Elsevier (sciencedirect.com)

- Digital Commons

(digitalcommons.harrisburgu.edu)

- Ijitee (ijitee.org)

Figure 2 shows the ratio of number of papers found for this research to number of selected papers used in this literature review.

\section{NUMBER OF PAPERS IN THE \\ DATABASES USING EXTRACTION C R I T E R I A}

틀 Number of papers found 틀 Number of selected papers

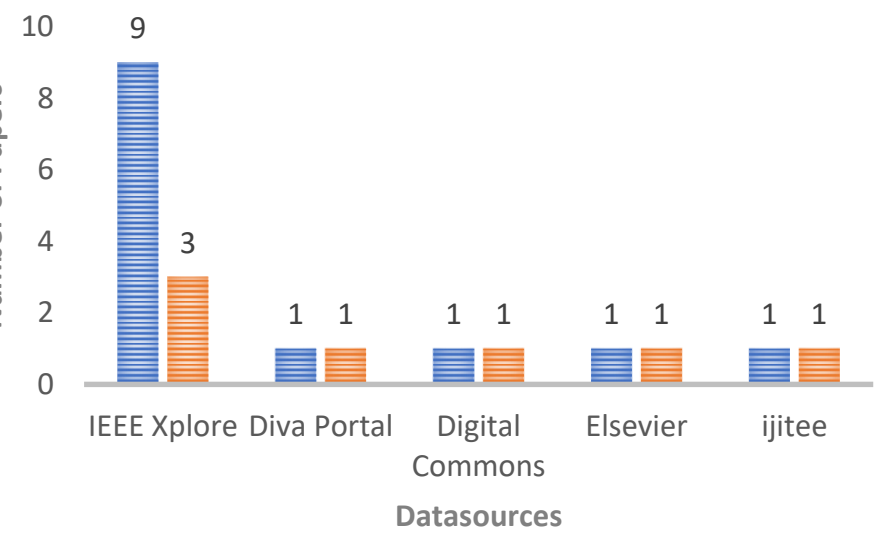

Figure. 2

RATIO OF NUMBER OF PAPERS FOUND TO SELECTED PAPERS

\section{Inclusion and Exclusion Criteria}

Following table 2 shows the inclusion and exclusion criteria to conduct this research on Scrum in GSD.

TABLE 2

INCLUSION AND EXCLUSION CRITERIA

\begin{tabular}{|l|l|l|}
\hline ID & Inclusion Criteria & \multicolumn{1}{|c|}{ Exclusion Criteria } \\
\hline 1. & Studies focus on & Studies do not focus on \\
\hline 2. & $\begin{array}{l}\text { Studies focus on } \\
\text { scrum and answer } \\
\text { any RQ. }\end{array}$ & \begin{tabular}{l} 
Studies are not applied on \\
\hline
\end{tabular} \\
\hline
\end{tabular}




\begin{tabular}{|l|l|l|l|}
\hline 3. & $\begin{array}{l}\text { Studies consider } \\
\text { challenges of GSD. }\end{array}$ & $\begin{array}{l}\text { Studies are not related to } \\
\text { RQ. }\end{array}$ & $\begin{array}{l}\text { QUANTITATIVE ANALYSIS OF SELECTED PAPERS FOR } \\
\text { SCRUM IN GSD }\end{array}$ \\
\hline 4. & $\begin{array}{l}\text { Studies are published } \\
\text { in English language. }\end{array}$ & $\begin{array}{l}\text { Studies are not written in B. Findings about Research Questions } \\
\text { English language. }\end{array}$ & $\begin{array}{l}\text { It includes qualitative analysis to answer the defined } \\
\text { RQs based on quantitative analysis. }\end{array}$ \\
\hline
\end{tabular}

This stage is performed to determine studies.

These are the following Quality Assessment Questions.

QA1: Does the study identify main objective of review?

QA2: Does the study identify role of scrum in GSD?

QA3: Does the study indicate the restrictions in use of scrum and determine strategies which are being used to deal with these restrictions?

\section{E. Data Extraction}

This phase is performed to extract data from selected primary studies which respond to RQs.

These are the following properties which are listed in Table 3 regarding the criteria for RQs.

TABLE 3

PROPERTIES OF RESEARCH QUESTIONS

\section{Properties Research Questions}

\begin{tabular}{ll}
\hline $\begin{array}{l}\text { Role of scrum in GSD } \\
\text { GSD using Agile }\end{array}$ & RQ1 \\
Methodologies & \\
\hline $\begin{array}{l}\text { Is Scrum fit for GSD? } \\
\text { Role of Scrum in GSD }\end{array}$ & RQ2 \\
\hline $\begin{array}{l}\text { Role of Scrum in GSD } \\
\text { Scrum practices in GSD }\end{array}$ & RQ3 \\
\hline
\end{tabular}

\section{F. Data Synthesis}

It is applied to collect quantitative and qualitative data that form evidence from selected papers that answer RQs.

\section{RESULTS}

\section{A. Selected Studies along the Years}

Figure 3 shows the quantitative analysis of selected studies on the issues of using scrum in GSD along the years.

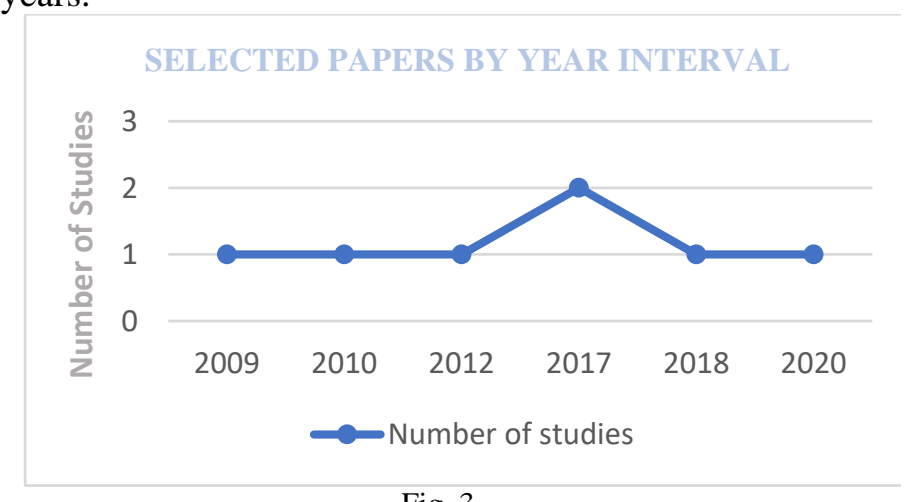

Fig. 3
Scrum used in the GSD helps to increase output efficiency.

'Figure. 4' shows the role of scrum in GSD (Kalluri, D., 2017) (Sriram \& Mathew, 2012).

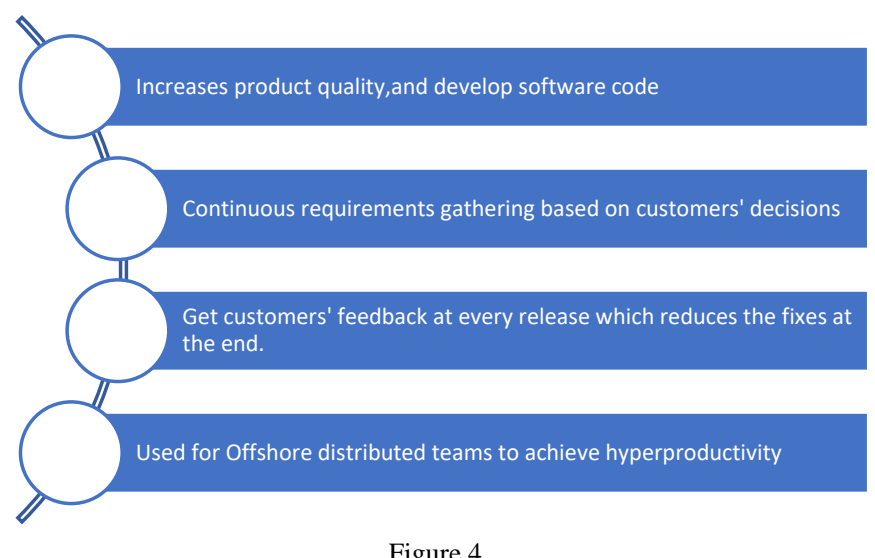

ROLE OF SCRUM IN GSD

RQ2) Factors cause restrictions using scrum for GSD

It has been found that, in distributed environments, communication related problems are notable challenges. Cultural differences between the dispersed team members may influence team coordination and communication. Due to large geographical areas between team members, there is a big difference in Time Zones. Shortage of meeting rooms is one of the main restrictions in GSD using Scrum (Hossain et al., 2009). Cultural distance is also an eminent challenge (Ansari \& Dodda, 2010).

RQ3) Strategies used to deal with restrictions and support Scrum practices

\section{Synchronous communication:}

Scrum teams used certain techniques to provide synchronous coordination where there is no gap in distributed team time. Changing the working hours and working from home etc achieve this. For example, a Scrum team used strict timeboxed meetings. The team members post their three regular Scrum questions or build a backlog to make the meetings fast and successful (Hossain et al., 2009).

\section{Team management}

It is found that splitting into small manageable subteams is a widely used strategy for managing a large dispersed team (Hossain et al., 2009).

\section{Office space}

It is revealed that to support a better communication and collaborative work, Scrum teams should use single meeting room for one team. In case of a person 
changing teams then he or she can be relocated to the new room (Hossain et al., 2009).

\section{V.LIMITATIONS}

As every empirical research, this research also has some limitations. This review, which deals with the use of Scrum practices in GSD, may have missed some papers that address Scrum practices in GSD. However, it is sure that it wouldn't be a systemic omission. During the data extraction process, it was found that adequate information was missing in some articles, but defining and categorizing the themes from the papers synthesized data included in the study. Since some of the selected studies do not include comprehensive details, there is a risk of inaccuracies that may have resulted from the extraction process. Despite the advantages of using Scrum practices identified in this review, these practices are also limited by contextual factors of some GSD projects and may be solved by using other techniques.

\section{CONCLUSION}

In conclusion, there is a growing demand in use of Scrum practices amongst other agile methodologies because Scrum proved to be best and fast method in GSD. However, there are many restricting factors i.e. communication problems, cultural differences, large geographical areas and lack of space. These are identified in reviewed studies shown in 'fig. 2 ' but can be overcome using strategies discussed in RQ3. Therefore, this review presents that to support the Scrum practices in various distributed projects, a distributed Scrum team should choose various models to reduce the complexities of the project delivery. Yet it is also concluded that Scrum practices may be limited by some contextual factors of Global Software Development's projects.

\section{REFERENCES}

[1] Ansari, R. J., \& Dodda, S. R. (2010). The use of SCRUM in global software development - an empirical study. Retrieved from http://www.divaportal.org/smash/record.jsf?pid=diva2\%3A833111\& dswid $=9434$.

[2] Bhavsar, K., Shah, V., \& Gopalan, S. (Jan 2020). Scrum: An Agile Process Reengineering in Software Engineering. Retrieved from http://www.ijitee.org/wpcontent/uploads/papers/v9i3/C8545019320.pdf
[3] Hossain, E., Babar, M. A., \& Paik, H. (Jul 2009). Using scrum in global software development: A systematic literature review. Retrieved from https://ieeexplore.ieee.org/document/5196931.

[4] Kalluri, D. (2017). Role of Agile Methods in Global Software Development. Retrieved from https://digitalcommons.harrisburgu.edu/pmgt_dandt/ 25/

[5] Lous, P., Kuhrmann, M., \& Tell, P. (May 20, 2017). Is scrum fit for global software engineering? Retrieved from https://ieeexplore.ieee.org/document/7976681.

[6] Mohammad Shameem, Rakesh Ranjan Kumar, Mohammad Nadeem, Arif Ali Khan (May 2020), Taxonomical classification of barriers for scaling agile methods in global software development environment using fuzzy analytic hierarchy process, Applied Soft Computing

[7] Sriram, R., \& Mathew, S. K. (Jun 2012). Global software development using agile methodologies: A review of literature. Retrieved from https://ieeexplore.ieee.org/document/6225837.

[8] Vallon, R., da Silva Estácio, B., Prikladnicki, R., \& Grechenig, T. (2018). Systematic literature review on agile practices in global software development. Retrieved from https://www.sciencedirect.com/science/article/abs/pi $\mathrm{i} / \mathrm{S} 0950584917302975$.

Appendix

TABLE 4. SELECTED PRIMARY STUDIES 


\begin{tabular}{|c|c|c|c|c|c|c|}
\hline & Ref & Topic & Author & Year & Place Published & Type \\
\hline 1 & [1] & $\begin{array}{l}\text { The Use of SCRUM } \\
\text { in Global Software - } \\
\text { An Empirical Study. }\end{array}$ & $\begin{array}{l}\text { Ansari and } \\
\text { Dodda }\end{array}$ & 2010 & Diva Portal & Journal \\
\hline 2 & {$[2]$} & $\begin{array}{l}\text { Scrum: An Agile } \\
\text { Process } \\
\text { Reengineering in } \\
\text { Software Engineering }\end{array}$ & $\begin{array}{l}\text { Bhavsar, Shah } \\
\text { and Gopalan }\end{array}$ & 2020 & Ijitee & Journal \\
\hline 3 & [3] & $\begin{array}{l}\text { Using Scrum in } \\
\text { Global Software } \\
\text { Development: A } \\
\text { Systematic Literature } \\
\text { Review. }\end{array}$ & $\begin{array}{l}\text { Hossain, Babar } \\
\text { and Paik }\end{array}$ & 2009 & IEEE & Journal \\
\hline 4 & [4] & $\begin{array}{l}\text { Role of Agile } \\
\text { Methods in Global } \\
\text { Software } \\
\text { Development. }\end{array}$ & Kalluri & 2017 & $\begin{array}{l}\text { Digital } \\
\text { Commons }\end{array}$ & Journal \\
\hline 5 & [5] & $\begin{array}{l}\text { Is scrum fit for Global } \\
\text { Software } \\
\text { Engineering? }\end{array}$ & $\begin{array}{l}\text { Lous, Kuhrmann } \\
\text { and Tell }\end{array}$ & 2017 & IEEE & Journal \\
\hline 6 & [6] & $\begin{array}{l}\text { Global Software } \\
\text { Development using } \\
\text { Agile Methodologies: } \\
\text { A Review of } \\
\text { Literature. }\end{array}$ & $\begin{array}{l}\text { Sriram and } \\
\text { Mathew }\end{array}$ & 2012 & IEEE & Journal \\
\hline 7 & [7] & $\begin{array}{l}\text { Systematic Literature } \\
\text { Review on Agile } \\
\text { Practices in Global } \\
\text { Software } \\
\text { Development. }\end{array}$ & $\begin{array}{l}\text { Vallon, da Silva } \\
\text { Estácio, } \\
\text { Prikladnicki and } \\
\text { Grechenig }\end{array}$ & 2018 & Science Direct & Journal \\
\hline
\end{tabular}

